Article

\title{
Analysis of Wildfires in the Mid and High Latitudes Using a Multi-Dataset Approach: A Case Study in California and Krasnoyarsk Krai
}

\author{
Lerato Shikwambana ${ }^{1,2, *(\mathbb{D})}$ and John Bosco Habarulema ${ }^{3,4}$ \\ 1 Earth Observation Directorate, South African National Space Agency, Pretoria 0001, South Africa \\ 2 School of Geography, Archaeology and Environmental Studies, University of the Witwatersrand, \\ Johannesburg 2050, South Africa \\ 3 Space Science Directorate, South African National Space Agency, Hermanus 7200, South Africa; \\ jhabarulema@sansa.org.za \\ 4 Department of Physics and Electronics, Rhodes University, Makhanda 6140, South Africa \\ * Correspondence: 1shikwambana@sansa.org.za
}

check for

updates

Citation: Shikwambana, L.;

Habarulema, J.B. Analysis of Wildfires in the Mid and High Latitudes Using a Multi-Dataset Approach: A Case Study in California and Krasnoyarsk Krai. Atmosphere 2022, 13, 428. https:// doi.org/10.3390/atmos13030428

Academic Editors: Madhu Gyawali, Rudra P. Aryal and Guenter Engling

Received: 14 January 2022

Accepted: 5 March 2022

Published: 7 March 2022

Publisher's Note: MDPI stays neutral with regard to jurisdictional claims in published maps and institutional affiliations.

Copyright: () 2022 by the authors. Licensee MDPI, Basel, Switzerland. This article is an open access article distributed under the terms and conditions of the Creative Commons Attribution (CC BY) license (https:/ / creativecommons.org/licenses/by/ $4.0 /)$.

\begin{abstract}
In this study, we investigate the emissions from wildfires in the mid latitude (California) and high latitude (Krasnoyarsk Krai) during the periods of 16-17 August 2020 and 28 July 2019, respectively. Wildfires are unique in themselves as they are driven by various factors such as fuel type, topology, and meteorology. In this study, we analyze whether there are any major variations in the emissions and transport of pollutants between two large wildfire cases in the mid latitude of California and high latitude of Krasnoyarsk Krai. The study is important to understand and characterize the emission regime from biomass burning of different land covers using a mutli-dataset approach. We analyze whether there are any major variations in the emissions and transport of pollutants from these wildfires. For example, the aerosol extinction coefficient profile showed smoke detected at the highest altitude of $9 \mathrm{~km}$ in Krasnoyarsk Krai, whereas in California the highest altitude was observed at approximately $6 \mathrm{~km}$. Moreover, large values of black carbon (BC) concentration were observed in Krasnoyarsk Krai approximately $7 \mu \mathrm{g} / \mathrm{m}^{3}$ compared to the $0.44 \mu \mathrm{g} / \mathrm{m}^{3}$ observed in California. Areas with an immense dense vegetation are prone to large emissions. The results from this case study suggest that high latitude wildfires emit more pollutants than mid latitude wildfires. However, more studies in the future will be conducted to conclude this observation and finding with certainty.
\end{abstract}

Keywords: smoke; aerosols; biomass burning; satellites; carbon monoxide; black carbon; CALIPSO; TROPOMI

\section{Introduction}

Fires can be ignited naturally by lightning or humans either accidentally or to accomplish management objectives such as clearing and reduction in fuel loads [1]. Wildfires affect a wide range of landcover types across the globe including boreal, temperate, and tropical forests, peatlands, shrublands and grasslands [2]. If not properly managed these wildfires can cause severe ecosystem and watershed damages within the different landcover types [3]. Three conditions need to be met to achieve an effective wildfire occurrence, namely (1) an ignition source (either lightning or human activities), (2) fuel source and (3) weather conditions conducive for fires [4]. Climate and weather are important drivers of wildfires across a range of timescales $[5,6]$. Precipitation, temperature, relative humidity, and wind speed are some instantaneous climatic conditions that influence wildfire behavior [4]. However, the feedback mechanisms between fire and climate interactions are still a great challenge and remain fundamentally uncertain [7]. Nonetheless, long-term changes in the climate and weather have resulted in some recent extreme wildfire events, including 
those that occurred in 2018 in the United States of America [8], 2019 in Brazil [9,10], and 2020 in Australia [11]. These wildfires resulted in vast burnt areas and large amounts of toxic gases and aerosols injected into the atmosphere. Furthermore, smoke can also travel up and reach the lower stratosphere thus increasing aerosol load with potential global effects [12-14]. High concentrations of aerosols and gases can affect radiation, clouds, and climate on a regional and/or global scale. Pollutants such as ozone, carbon monoxide (CO), nitrogen dioxide $\left(\mathrm{NO}_{2}\right)$, sulphur dioxide $\left(\mathrm{SO}_{2}\right)$, and particulate matter $(\mathrm{PM})$ emitted by fires have impact on air quality and the human health at a local-to-regional scale [15]. At a global scale, fire emission has significant impacts on atmospheric and biogeochemical cycles and the Earth's radiative budget [16,17].

Although wildfires happen over relatively short periods (i.e., several days), their emissions can have catastrophic consequences in the lower troposphere. For example, Guo et al. [18] showed that $\mathrm{CO}_{2}$ released into the atmosphere by wildfires may convert forests from carbon sinks into net sources, which in turn contributes to global warming and affects the carbon cycle. Furthermore, black carbon (BC) particles can change their hygroscopic properties and sizes, which affects the mechanisms and rates of their deposition to the surface when transported in the atmosphere [19]. BC particles absorb solar radiation in the visible region of the spectrum directly in the air and re-emit energy in the infrared spectrum which leads to heating of the atmosphere [19].

Ground based instruments, reanalysis modelled data and space borne instruments have been used to measure emissions from wildfires. The vertical distribution and transport of aerosols from wildfires has been observed from the Cloud-Aerosol LiDAR and Infrared Pathfinder Satellite Observations (CALIPSO) satellite. Furthermore, CALIPSO can provide aerosol sub-type information which is crucial for aerosol classification. Several studies have used CALIPSO to study emissions from wildfires [11,20-22]. On the other hand, the information on the spatial distribution of aerosols from biomass burning (BB) is also paramount. The Modern-Era Retrospective analysis for Research and Applications, Version 2 (MERRA-2) and Moderate Resolution Imaging Spectroradiometer (MODIS) are the two mostly used datasets to retrieve BB aerosols. MERRA-2 products such as BC and organic carbon (OC) are widely used to understand the BB aerosol emission from wildfires [23,24]. The aerosol optical depth (AOD) product from MODIS also gives valuable information pertaining to the wildfire emissions [25]. Low and AOD values indicate less and more/thick smoke from the biomass burning respectively. Another important parameter obtained from MODIS is the aerosol angstrom parameter (AAP). AAP normally decreases exponentially with wavelength over the visible and near-infrared spectral region $[26,27]$. AAP is defined as

$$
\alpha_{a b s}(\gamma)=\alpha_{0} \gamma^{\mathrm{AAP}}
$$

where $\alpha_{a b s}$ denotes the aerosol absorption coefficient, $\alpha_{0}$ is a wavelength-independent constant (which equals the absorption coefficient at the wavelength of $1 \mu \mathrm{m}$ ) and $\gamma$ is the wavelength. The AAP describes absorption variation with respect to wavelength and is significantly influenced by particle size, shape, and chemical composition. AAP has been widely used for aerosol characterization because it is assumed to be a specific property of each aerosol species [27]. The knowledge of dispersion of pollutants in the process of lifting, and the long-range transport of atmospheric aerosols and gases from an emission site is vital. Therefore, trajectories of air masses are useful in this regard. The Hybrid SingleParticle Lagrangian Integrated Trajectory (HYSPLIT) model available from the National Oceanic and Atmospheric Administration (NOAA, Washington, DC, USA) Air Resources Laboratory (ARL, College Park, MD, USA) is the most utilized tool for the analysis of air mass trajectories. The HYSPLIT model can estimate the forward or backward trajectory of an air mass. A backward trajectory analysis is helpful for ascertaining the origins and sources of pollutants, while a forward trajectory analysis is helpful for determining the dispersion of pollutants. 
The focus of this study is to assess the emissions of two big wildfires in the mid latitude (California) and high latitude (Krasnoyarsk Krai) during the summer season. These wildfires occurred during 16-17 August 2020 (California) and 28 July 2019 (Krasnoyarsk Krai). We aim to check if there are any similarities or differences in the emission regime in the two wildfires. We also assess the impact the emissions have on the temperature and relative humidity vertical profiles. The paper is organized as follows: the study areas are discussed in Section 2, while Section 3 discusses the datasets used in this study. The results and discussion are presented in Section 4, and the conclusions are summarized in Section 5.

\section{Study Areas}

The study area in Figure 1 consisted of two major wildfires' sites which occurred in the United States of America (USA) and Russian Federation on 16-17 August 2020 and 28 July 2019, respectively. These are some of the biggest wildfires recorded in the period of 2015-2020. The first study site, Figure 1a, is located in California $\left(36.78^{\circ} \mathrm{N}\right.$, $\left.119.42^{\circ} \mathrm{W}\right)$, in the mid latitude. However, the wildfires here were mostly concentrated in northern California, in the Sacramento and Sierra Nevada Mountains region. Overall, California has a Mediterranean-like climate with warm dry summers and mild wet winters. The area is mostly characterized by hardwood forests, hardwood woodland and conifer forests. Furthermore, California is the largest and most diverse agricultural state in the United States of America that generates an overall agricultural production value of \$50.5 billion [28]. Krasnoyarsk Krai $\left(64.25^{\circ} \mathrm{N}, 95.11^{\circ} \mathrm{E}\right)$, in the high latitude (see Figure 1b), is part of the Siberian Federal District in the Russian Federation. The area is mostly covered by forests and open woodlands. Approximately $71 \%$ of the area is covered by forests [29]. The area is also a home to many animals such as sable, squirrel, arctic fox, fox, ermine, and reindeer [30]. The region has three climatic zones: arctic, sub-arctic and temperate. The area is characterized by long winters and short summers. The average temperature in winter is $-36{ }^{\circ} \mathrm{C}$ in the north and $-18^{\circ} \mathrm{C}$ in the south. Summer temperature can reach up to approximately $25^{\circ} \mathrm{C}$ in July [31]. The wildfires of 28 July 2019 were mostly concentrated in the Yakutsk region, in Krasnoyarsk Krai. Figure 1c shows the MODIS fire map over California and Krasnoyarsk Krai. There were more fires detected in Krasnoyarsk Krai than in California. This result also implies that there were more burned areas in Krasnoyarsk Krai compared to California. Lastly, the burned areas were approximately $18,000 \mathrm{~km}^{2}$ and approximately 43,000 km² for California and Krasnoyarsk Krai, respectively. In other words, the burned area over Krasnoyarsk Krai was almost 2.4 times the burned area observed in California. 

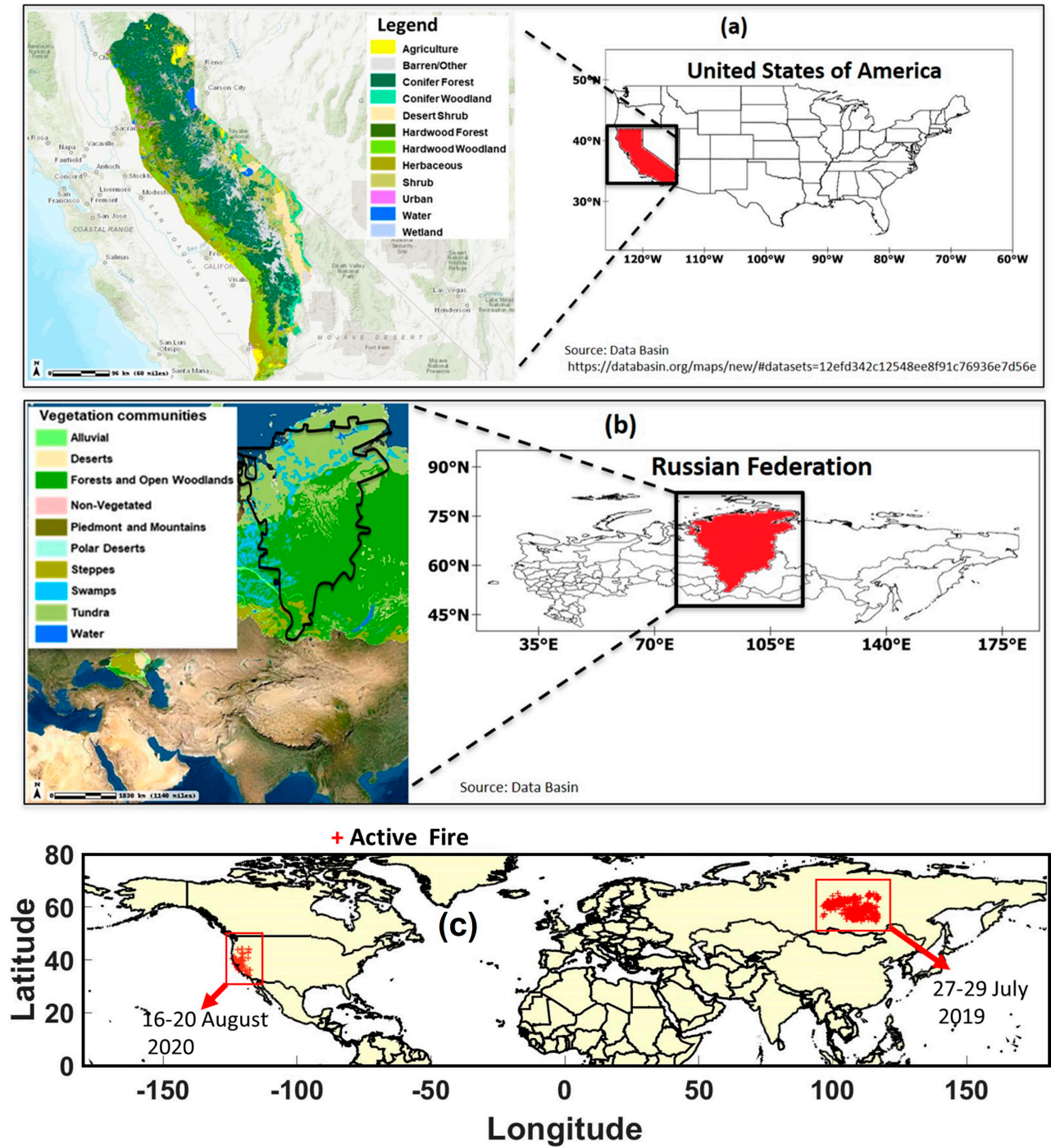

Figure 1. A map showing the land cover in (a) California (United States of America) and (b) Krasnoyarsk Krai (Russian Federation). (c) Fire map showing active fires in California (16-20 August 2020) and Krasnoyarsk Krai (27-29 July 2019).

\section{Data}

\subsection{Cloud-Aerosol LiDAR and Infrared Pathfinder Satellite Observations (CALIPSO)}

CALIPSO provides insight into the role that atmospheric aerosols and clouds play in regulating Earth's weather, climate, and air quality. There are three instruments on board the CALIPSO, namely, the wide field camera (WFC), the infrared imaging radiometer (IIR) and the Cloud-Aerosol LiDAR with Orthogonal Polarization (CALIOP). CALIOP is a nearnadir viewing two-wavelength (532 $\mathrm{nm}$ and $1064 \mathrm{~nm}$ ) polarization-sensitive LiDAR [32]. The instrument operates continuously, acquiring 1.7 million laser shots every $24 \mathrm{~h}$ and providing observations during both day and night portions of the orbit [33]. One of the advantages of the CALIOP is its capability of retrieving vertical distributions of aerosols and clouds with high vertical resolution [34]. The aerosol and cloud profile products are reported at a uniform spatial resolution of $60 \mathrm{~m}$ vertically.

The CALIOP level 2 aerosol products provide vertically resolved aerosol extinction as well as aerosol type [35]. There are three types of level two data products: layer products, profile products, and the vertical feature mask (VFM). Layer products provide layer-integrated or layer-averaged properties of detected aerosol and cloud layers, profile products provide retrieved extinction and backscatter profiles within these layers and the VFM provide information on cloud and aerosol locations and types [33]. More details on 
the algorithm developed to identify aerosol and cloud layers, and to retrieve a variety of optical and microphysical properties is discussed by Winker et al. [33] and Vaughan et al. [36]. In this study aerosol and backscatter extinction coefficient, temperature, relative humidity, and aerosol layer profiles are used.

\subsection{Sentinel-5P (TROPOMI)}

Sentinel-5P measures and provides information about atmospheric trace gases, aerosols, and cloud distribution which affects air quality and climate. Sentinel-5P has an instrument on board called the TROPOspheric Monitoring Instrument (TROPOMI). TROPOMI is a hyperspectral imaging spectrometer that measures the Earth's radiance at the ultravioletvisible (UV-VIS, 267-499 nm), near-infrared (NIR, 661-786 nm), and shortwave infrared (SWIR, 2300-2389 nm) wavelengths over ground pixels as small as $7.0 \mathrm{~km} \times 3.5 \mathrm{~km}$. It has a swath width of $2600 \mathrm{~km}$ enabling it an almost daily global coverage. TROPOMI has the capability to map a multitude of trace gases such as $\mathrm{NO}_{2}$, ozone, formaldehyde, $\mathrm{SO}_{2}$, methane, $\mathrm{CO}$, and aerosols. More details on sentinel-5P are found in Theys et al. [37], Tilstra et al. [38] and Verhoelst et al. [39]. In this study, the CO product is used.

\subsection{Moderate-Resolution Imaging Spectroradiometer (MODIS)}

MODIS is the instrument aboard the NASA's Terra and Aqua satellites. It can acquire high radiometric-sensitive data (12 bit) in 36 spectral bands with wavelengths ranging from 0.4 to $14.385 \mu \mathrm{m}$. The channels with wavelengths ranging from 0.47 to $2.12 \mu \mathrm{m}$ are used to retrieve aerosol characteristics, and daily level aerosol optical thickness data are produced at the spatial resolution of $10 \mathrm{~km} \times 10 \mathrm{~km}$ worldwide. Aerosol data are contained in the MODIS aerosol product which monitors the ambient aerosol optical thickness over the oceans and land globally. Furthermore, MODIS can derive aerosol size distribution and aerosol type, i.e., "fine" aerosols (e.g., anthropogenic/pollution) and "course" aerosols (e.g., natural particles such as dust). More details on the specifications and products of MODIS can be found in Justice et al. [40]. The dataset used in this study is the aerosol angstrom parameter.

\subsection{Modern-Era Retrospective Analysis for Research and Applications Version 2 (MERRA-2)}

MERRA-2 was developed to replace the original MERRA dataset because of the advances made in the assimilation system that enable assimilation of modern hyperspectral radiance and microwave observations, along with GPS-Radio Occultation datasets (https:/ / gmao.gsfc.nasa.gov / reanalysis /MERRA-2/, accessed on 10 January 2022). MERRA2 for the first time includes analyzed aerosol fields that are radiatively coupled to the atmosphere. MERRA-2 incorporates system changes and fundamental developments in modelling and data assimilation, including (1) the assimilation of aerosol observations that can interact with atmospheric radiative processes; $(2)$ constraining mass conservation even with the analysis of water vapor, allowing a global balance between evaporation and precipitation; (3) the use of a cube sphere to reduce the effect of grid point singularities at the pole, allowing for improved polar circulation; (4) an updated radiative transfer model to permit the assimilation of data from many more instruments than could have been included in MERRA; and (5) the inclusion of new observational forcing for the land model to provide more stable land feedback processes [41]. MERRA-2 is produced using version 5.12 .4 of the GEOS DAS. Gridded data are released at a $0.625^{\circ}$ longitude $\times 0.5^{\circ}$ latitude resolution on 72 sigma-pressure hybrid layers between the surface and $0.01 \mathrm{hPa}$ [42]. More details on MERRA-2 can be found in Gelaro et al. [43], Buchard et al. [44] and Randles et al. [41]. The datasets used in this study is black carbon concentration.

\subsection{Hybrid Single-Particle Lagrangian Integrated Trajectory Model (HYSPLIT)}

HYSPLIT is a complete system for computing simple air parcel trajectories to complex dispersion and deposition simulations [45]. One of the most common model applications is a back-trajectory analysis to determine the origin of air masses and establish source- 
receptor relationships [46]. The trajectory frequency option starts a trajectory from a single location and height every 3, 6, or $12 \mathrm{~h}$ for the duration of the meteorology file, and then sum the number of times the trajectories pass over each grid cell on a userdefined grid. The trajectories are calculated using the vertical motion calculation method (http: / / ready.arl.noaa.gov / HYSPLIT.php, accessed on 10 January 2022). There are many uncertainties in the calculation of trajectories, and these arise from possible errors in input meteorological fields and numerical methods employed. To reduce uncertainties associated with a single trajectory, HYSPLIT can be run in the ensemble mode to generate multiple trajectories from a single meteorological field [47]. In this study, forward trajectories were produced to investigate the dispersion of emissions.

A summary of the parameters used in this study is shown in Table 1.

Table 1. Data used to study emissions from wildfires.

\begin{tabular}{|c|c|c|}
\hline Input Data Source & Product Used & Output Data \\
\hline CALIPSO (532 nm) & $\begin{array}{c}\text { Aerosol profile } \\
\text { Temperature profile }\left({ }^{\circ} \mathrm{C}\right) \\
\text { Relative humidity profile }(\%) \\
\text { Aerosol layer fraction profile }\end{array}$ & $\begin{array}{l}\text { Vertical height profiles } \\
\text { from } 0-12 \mathrm{~km}\end{array}$ \\
\hline $\begin{array}{l}\text { Sentinel-5P } \\
(270-2385 \mathrm{~nm})\end{array}$ & $\mathrm{CO}$ density $\left(\mathrm{mol} / \mathrm{m}^{2}\right)$ & $\begin{array}{l}\text { Spatial distribution map of } \mathrm{CO} \\
\text { Timeseries plot of } \mathrm{CO}\end{array}$ \\
\hline MODIS (550 nm) & $\begin{array}{l}\text { Aerosol angstrom parameter } \\
\text { (AAP) }\end{array}$ & Timeseries plot of AAP \\
\hline MERRA-2 (550 nm) & $\begin{array}{l}\text { Black carbon concentration } \\
\left(\mu \mathrm{g} / \mathrm{m}^{3}\right)\end{array}$ & Timeseries plot of BC concentration \\
\hline HYSPLIT model & $\begin{array}{c}5 \text { days forward air mass } \\
\text { trajectories }\end{array}$ & $\begin{array}{c}\text { Maps showing trajectories } \\
\text { of air masses }\end{array}$ \\
\hline
\end{tabular}

\section{Results and Discussion}

\subsection{TROPOMI CO Observation}

Figure $2 \mathrm{a}, \mathrm{b}$ show the spatial distribution of $\mathrm{CO}$ column density originating from biomass burning during 1-14 August and 15-22 August 2020, while the daily mean CO $\left(\mathrm{mol} / \mathrm{m}^{2}\right)$ changes for August in 2018-2020 are shown in Figure 2c for the mid-latitude (California) fire. Figure 2d,e is similar to Figure 2a,b, but for high-latitude fire over Krasnoyarsk Krai which occurred during July 2019. Similar to Figure 2c, Figure $2 \mathrm{f}$ shows the daily mean CO for July 2018-2020 over Krasnoyarsk Krai. In general, CO is a by-product of incomplete combustion of carbon-containing fuels. For California, low-to-moderate averaged $\mathrm{CO}$ column density values $\left(0.02-0.035 \mathrm{~mol} / \mathrm{m}^{2}\right)$ were observed between 1-14 August 2020 before the large fire started (see Figure $2 \mathrm{a}$ ). The $\mathrm{CO}$ observed is likely emitted from motor vehicles, power plants and incinerators. However, high values of averaged $\mathrm{CO}$ column density $\left(0.04-0.05 \mathrm{~mol} / \mathrm{m}^{2}\right)$ were observed between 15-22 August 2020 (see Figure 2b). The high $\mathrm{CO}$ column density was due to the biomass burning from fire. The CO was mostly concentrated in central California which is characterized by hardwood forests, hardwood woodland and conifer forests (see Figure 1). Hardwood was the major fuel for the fire. Hardwoods are typically heavier, denser, absorb less water, and burn slowly allowing for fires of high temperatures which makes them best suited to large fires. A comparison of the 2018, 2019 and 2020 daily mean CO column density timeseries in the month of August shows the impact of large biomass burning in $\mathrm{CO}$ emissions (see Figure 2c). The biomass burning of 2020 resulted in approximately 16 times the emissions of $\mathrm{CO}$ observed in 2018 and 2019. The timeseries also shows the presence of moderate to high CO column density for about 4 days after the start of the fire, generally, $\mathrm{CO}$ has a long lifetime in the atmosphere [48]. 

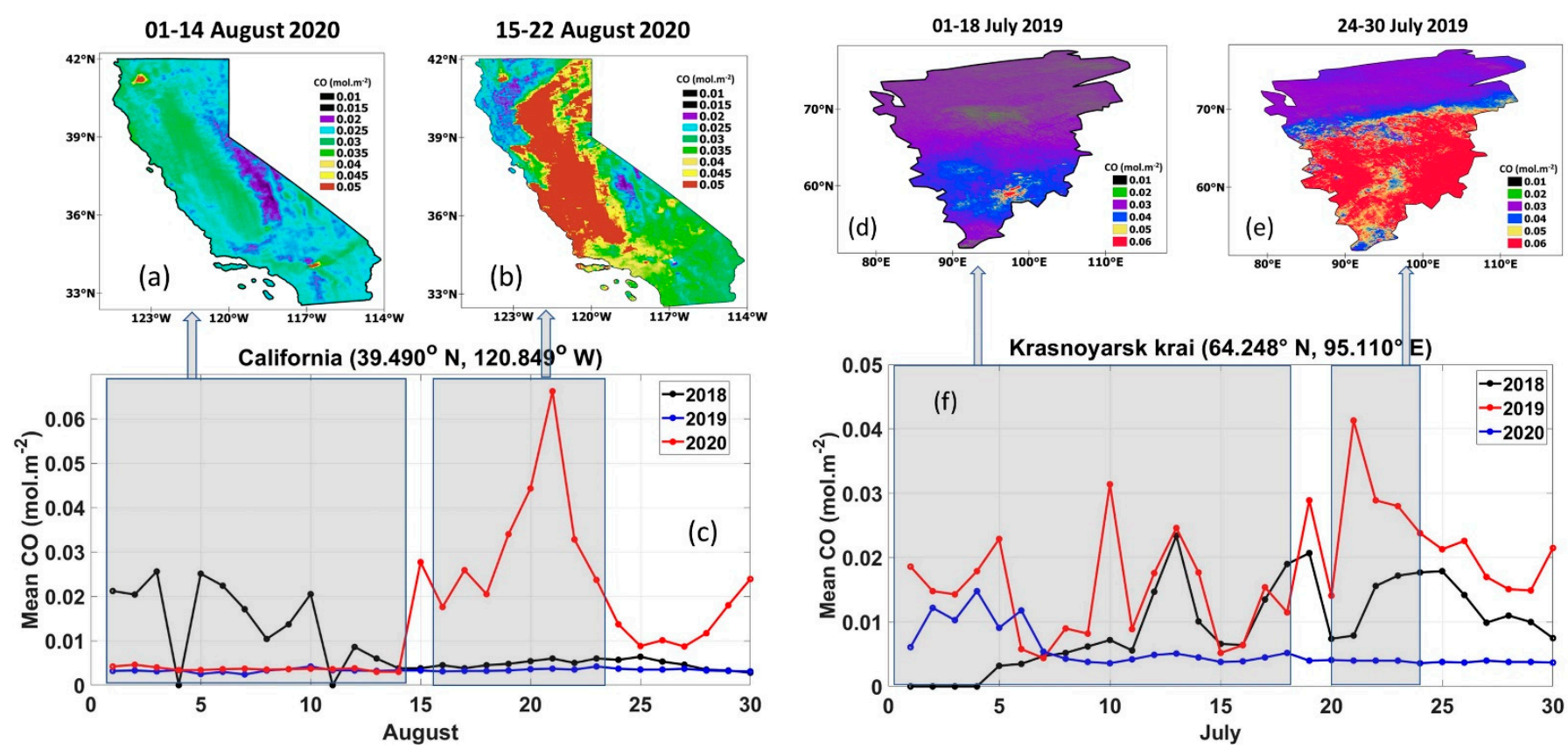

Figure 2. CO distribution over California on (a) 1-14 August 2020 and (b) 15-22 August 2020. (c) Daily mean BC column burden for the period of 1-30 August 2020. CO distribution over Krasnoyarsk Krai on (d) 1-18 July 2019 and (e) 24-30 July 2019. (f) Daily mean BC column burden for the period of 1-30 July 2019.

Over Krasnoyarsk Krai, Figure 2d shows that moderate-averaged CO column density values between 0.03 and $0.04 \mathrm{~mol} / \mathrm{m}^{2}$ were dominant across the region in the period of 01-18 July 2019, before the start of the wildfire. The CO measured is likely emitted from mining, industrial activities, and motor vehicles. However, high values of averaged $\mathrm{CO}$ column density, between 0.05 and $0.06 \mathrm{~mol} / \mathrm{m}^{2}$, were observed in the south of Krasnoyarsk Krai in the period of 24-30 July 2019 (see Figure 2e). The major contributor of the CO was from the biomass burning due to the wildfires. The south of Krasnoyarsk Krai is characterized by forests and open woodlands (see Figure 1b), which makes it a good fuel loading candidate for large fires. Figure $2 \mathrm{f}$ shows a comparison of the 2018, 2019 and 2020 daily mean CO column density timeseries for the month of July 2019. Generally, the 2019 plot (red) showed higher CO column density values than the 2018 and 2020 graphs. The high $\mathrm{CO}$ column density values were primarily from the large fires that occurred in the July 2019 period.

\section{2. $B C$ and $A A P$ Timeseries}

Black carbon (BC) is a carbonaceous aerosol by-product which arises from the incomplete combustion of fossil fuels or biomass burning [49]. It is also one of the largest contributors to fine particulate matter $\left(\mathrm{PM}_{2.5}\right)$ [50]. It has a short lifetime spanning from days to weeks after being released into the atmosphere. Figure 3a shows the timeseries of the BC concentration for the month of August for the years 2018, 2019 and 2020. High $\mathrm{BC}$ concentrations values peaks at approximately 0.43 and $0.46 \mu \mathrm{g} / \mathrm{m}^{3}$ are observed in the year 2020. These are due to the biomass burning in central California. The burning of vegetation in the forest was responsible for the release of $\mathrm{BC}$ aerosols from the burning process. Compared to the 2018 and 2019 years the BC concentration was much higher (approximately 40 times). The Aerosol Angstrom parameter (AAP) is important as it can indicate with some uncertainty the aerosol observed. AAP of an aerosol sample close to 1 is considered to be $\mathrm{BC}$ rich aerosol from fossil fuel burning, and larger AAP values are understood to indicate aerosols from biomass/biofuel burning or dust [51]. Figure $3 b$ shows large values of AAP approximately 2 for the year 2020, which is a contribution from the wildfire. Organic aerosols which are also released during wildfires could be the 
main contributor to the large AAP value. Compared to the other two years, the year 2020 produced the highest value of AAP in the period 20-25 August. High AAP values on 5 August 2018 could also be due to wildfires.
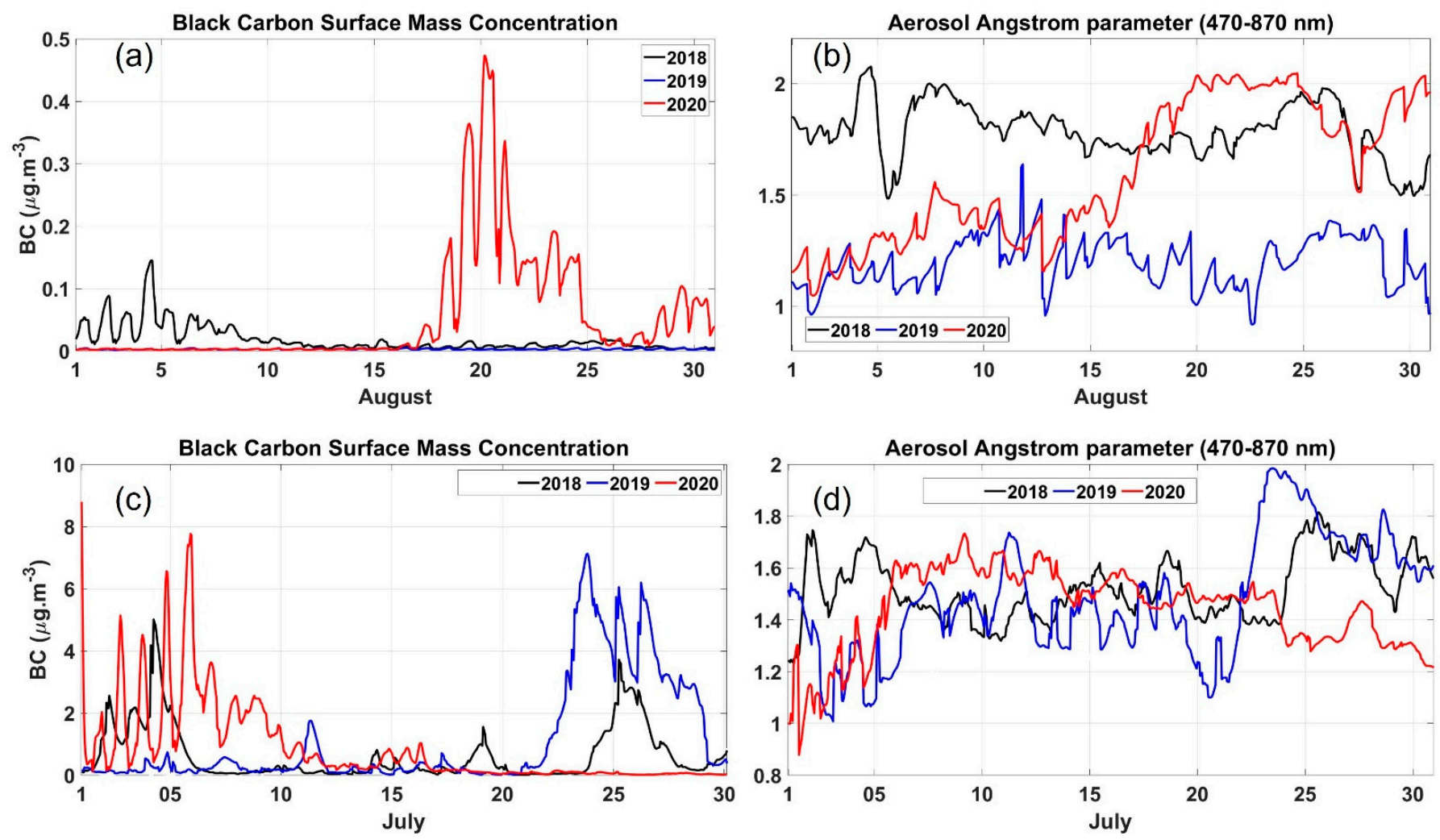

Figure 3. California (a) hourly averaged BC surface concentration for the month of August in the 2018, 2019 and 2020 period. (b) Daily Aerosol Angstrom parameter for the month of August in the 2018, 2019 and 2020 period. Krasnoyarsk Krai (c) Hourly averaged BC surface concentration for the month of July in the 2018, 2019 and 2020 period. (d) Daily Aerosol Angstrom parameter for the month of July in the 2018, 2019 and 2020 period.

Figure $3 \mathrm{c}$ shows the timeseries of the $\mathrm{BC}$ concentration for the month of July for the years 2017, 2018, 2019 and 2020. Large BC concentration peaks are observed in the 2019 and 2020 years. In the year 2019 large BC concentration peaks of approximately 7, 6 and $6 \mu \mathrm{g} / \mathrm{m}^{3}$ are observed on 23, 25 and 27 July 2019, respectively. These peaks are due to biomass burning from the wildfire. The AAP plot in Figure $3 \mathrm{~d}$ for the year 2019, show AAP values between 1.6 and 1.9 for the period of 25 to 30 July 2019. These values indicate aerosols from biomass burning such as organic carbon. In general, AAP values depended strongly on modified combustion efficiency, i.e., a measure of fire combustion conditions (flaming against smoldering) [51] and it also depends on the fuel type.

\subsection{CALIOP Aerosol Extinction Coefficient Vertical Height Profiles}

Figure $4 \mathrm{a}, \mathrm{b}$ shows the aerosol extinction coefficient height profile over California on 17 and 19 August 2020. These were the only CALIOP overpass days during the wildfire episode. The highest aerosol extinction coefficient of $0.058 \mathrm{~km}^{-1}$ was observed near the ground on 17 August 2020 (see Figure 4a). Peaks around the 2 and $6 \mathrm{~km}$ heights, respectively, are from the mixture of smoke and aerosols, due to biomass burning. Generally, the burning of hardwood produces more smoke than the burning of softwood or grasses. Therefore, in this study, since the major fuel for the fire is hardwood trees, most of the smoke is produced from them burning. The excessive burning of the trees results in large smoke travelling up into mid-troposphere heights. On 19 August 2020 the highest aerosol extinction coefficient 
of $0.073 \mathrm{~km}^{-1}$ was observed near the ground (see Figure $4 \mathrm{~b}$ ). This means that there was more aerosol loading $(+20.5 \%)$ on the 19th compared to the 17 th of August. This could be due to the continuation of the smoldering process after the flaming process of the fire has completed.
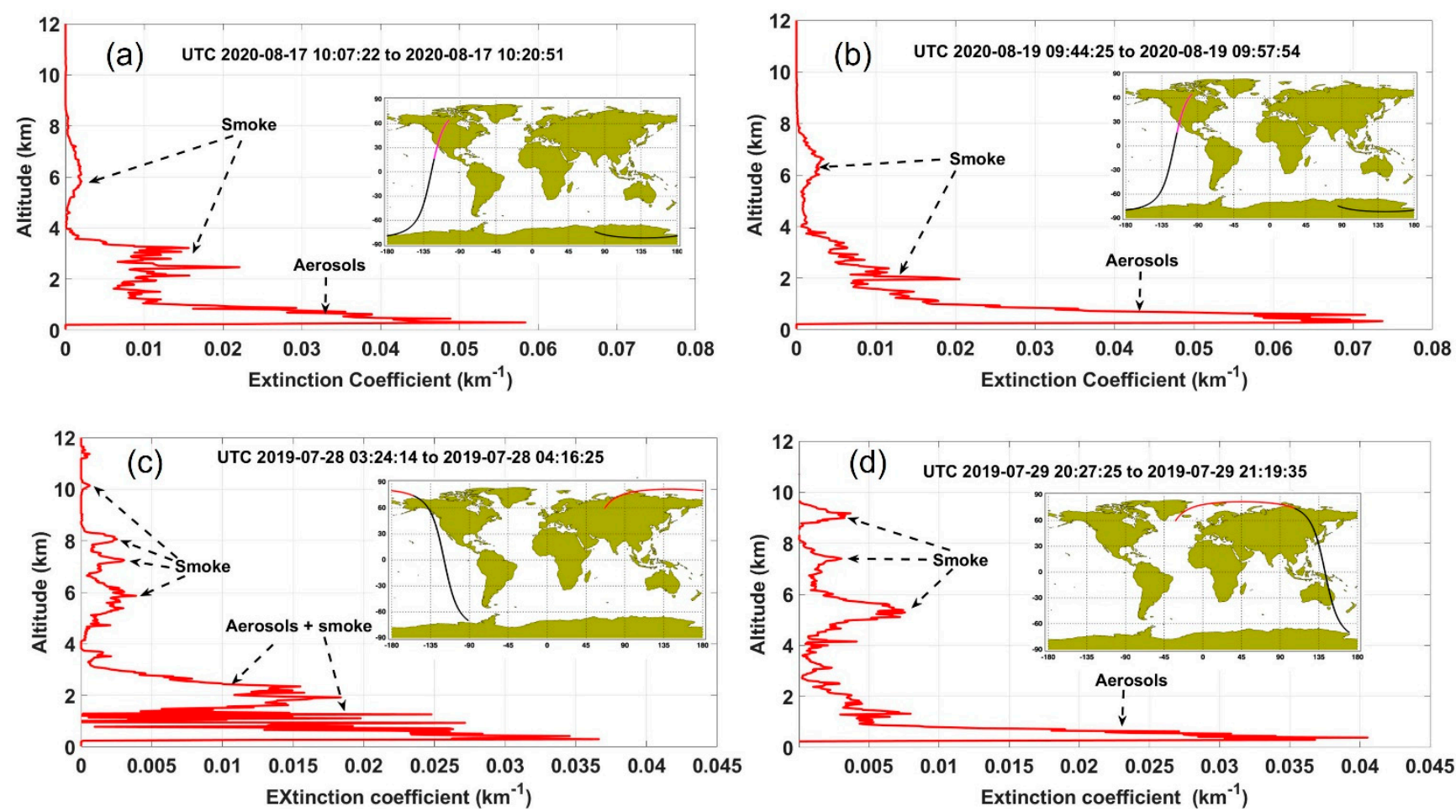

Figure 4. CALIOP vertical height profile of aerosols extinction coefficient over California for the period of (a) 17 August 2020 and (b) 19 August 2020. CALIOP vertical height profile of aerosols extinction coefficient over Krasnoyarsk Krai for the period of (c) 28 July 2019 and (d) 29 July 2019.

Figure 4c,d shows the aerosol extinction coefficient height profile over Krasnoyarsk Krai on 28 and 29 July 2019. On 28 July 2019, Figure 4c shows peaks in the lower, middle, and higher altitudes of the troposphere. The lower altitude $(<2 \mathrm{~km})$ shows moderate to high values of the aerosol extinction coefficient in the range of 0.015 to $0.037 \mathrm{~km}^{-1}$. This layer is the planetary boundary layer (PBL) where most of the pollutants reside. The PBL and atmospheric conditions influence the plume-rise spatial and temporal distributions [22]. The middle and high altitude of the troposphere, on the other hand, show low values of the aerosol extinction coefficient. Among other pollutants, smoke is observed in the middle altitude i.e., $6,7,8 \mathrm{~km}$ with the aerosol extinction coefficient value of approximately $0.004 \mathrm{~km}^{-1}$. The smoke particles are likely generated during the smoldering phase of combustions and transported to the upper troposphere. A small peak with an aerosol extinction coefficient of $<0.001 \mathrm{~km}^{-1}$ is observed at the upper troposphere at an altitude of approximately $10 \mathrm{~km}$. On 29 July 2019 (see Figure 4d), distinct peaks are observed also in the lower, middle, and higher altitudes of the troposphere. A high value of the aerosol extinction coefficient $\left(0.041 \mathrm{~km}^{-1}\right)$ is observed at the lower troposphere at an altitude of approximately $0.5 \mathrm{~km}$. This is due to the high aerosol loading in the PBL. A large smoke plume of approximately $1 \mathrm{~km}$ is observed between the 5 and $6 \mathrm{~km}$ altitude, with a low aerosol extinction coefficient of $0.008 \mathrm{~km}^{-1}$. In the upper troposphere a smoke plume of approximately $0.5 \mathrm{~km}$ is observed at an altitude of $9 \mathrm{~km}$, with a low aerosol extinction coefficient of $0.003 \mathrm{~km}^{-1}$. The strength of deep convection is one phenomenon which lifts smoke to the upper troposphere. 


\subsection{Temperature, Relative Humidity, Backscatter Coefficient and Aerosol Layer Profiles}

Figure 5a shows the vertical profile of the temperature from the ground to the upper troposphere $(12 \mathrm{~km})$ for days without wildfires and 1 day of the wildfires. Generally, the temperature of the troposphere is highest near the surface of the Earth and decreases with altitude up to the tropopause $(8 \mathrm{~km})$, and the temperature increases again with altitude. However, the temperatures at the tropopause for the days without wildfires $(2,15$ and 28 August 2020) have slightly higher temperatures i.e., $-62{ }^{\circ} \mathrm{C},-64{ }^{\circ} \mathrm{C}$ and $-68{ }^{\circ} \mathrm{C}$ respectively, compared to the day of the wildfire 19 August 2020 which has a temperature of $-72{ }^{\circ} \mathrm{C}$. During wildfires, large amounts of trace gases are released into the atmosphere. The distribution of these trace gases affects the vertical temperature distribution by absorbing and emitting longwave radiation, and also by absorbing ultraviolet radiation from the sun. Therefore, on 19 August 2020 large amounts of $\mathrm{CO}_{2}$ and $\mathrm{CO}$ gases were injected into the atmosphere during the biomass burning. These gases are responsible for altering the temperature in the tropopause. This observation agrees with the fact that the vertical temperature profile is extremely sensitive to changes in the solar irradiance and the concentrations of trace gases. Relative humidity, on the other hand, shows variability but the overall trend shows that relative humidity decreases with increasing altitude (see Figure $5 b$ ). The maximum relative humidity of approximately $75 \%$ is near the surface on the 2 and 15 August 2020 which are days without the wildfire. On the day of the wildfire, 19 August, relative humidity is at its highest at approximately $68 \%$ at an altitude less than $1 \mathrm{~km}$ (approximately $0.78 \mathrm{~km}$ ). This could be due to the less stable PBL from the wildfire emissions. However, an interesting observation is seen above the tropopause. On the wildfire day (19 August 2020), relative humidity decreases at slightly high altitudes than the days without fires. For example, a relative humidity value of $20 \%$ on 2 and 15 August is observed at an altitude of approximately $9 \mathrm{~km}$, whereas on 19 August a $20 \%$ relative humidity is observed at an altitude of approximately $11 \mathrm{~km}$. It is not clear from this observation how the emissions from the wildfires influenced the shift in the altitude, as the highest emission were detected at approximately $7 \mathrm{~km}$ (see Figure $4 \mathrm{~b}$ ). The aerosol backscatter coefficient profiles are shown in Figure 5c. A strong peak is observed at approximately $0.2 \mathrm{~km}$ on 19 August 2020 which corresponds to the highest value of the aerosol backscatter coefficient of approximately $13.2 \mathrm{Mm}^{-1} \cdot \mathrm{sr}^{-1}$. This high backscatter is from biomass burning aerosols emitted from the wildfire. Carbonaceous aerosols such as black carbon and organic carbon are the main aerosols released during the burning. Moreover, on 19 August 2020 two small peaks are observed at altitudes of approximately 2.2 and $3.2 \mathrm{~km}$ with low values of the aerosol backscatter coefficient $>0.5 \mathrm{Mm}^{-1} \cdot \mathrm{sr}^{-1}$ which are likely to be aerosols and smoke. The aerosol layer fraction in Figure $5 \mathrm{~d}$ gives a better view of the aerosol vertical profiles for the different days. Two distinct peaks are observed at altitudes of 0.36 and $6.7 \mathrm{~km}$ corresponding to layers of aerosols. These peaks are observed on 19 and 28 August 2020. However, the 19 August 2020 profile shows a slightly large values of the aerosol layer fraction compared to the 28 August 2020 profile. An interesting observation is on 28 August, the profile shows that even after the wildfires, that started around 16 August, large amounts of aerosols were still present. Biomass burning aerosols are the main contributor to the aerosol layers observed.

Figure 6 shows changes in CALIOP vertical height profiles of temperature, relative humidity, backscatter coefficient and aerosol layer fraction over Krasnoyarsk Krai. The temperature profiles do not show many variations among the days under study (see Figure 6a). This result suggests that there was not much difference in the air temperature between the day of the wildfire and days without the wildfires. In general, variations in tropopause height significantly depend upon the changes in upper tropospheric and lower stratospheric temperature. An increase in tropospheric temperature decreases the tropopause height. The tropopause height is observed at approximately $9 \mathrm{~km}$ at a temperature of approximately $-62{ }^{\circ} \mathrm{C}$ on 16 and 29 July 2019 , and at a temperature of approximately $-61^{\circ} \mathrm{C}$ on 21 and 26 July 2019. Relative humidity profiles show some variability, but the overall trend shows that relative humidity decreases with increasing altitude (see Figure $6 b$ ). The profile shows 
some perturbations of the relative humidity at an altitude of approximately $5 \mathrm{~km}$. These changes are influenced by the smoke and aerosols detected in this region, see Figure 5 . Relative humidity is higher $(68 \%)$ on 29 July compared to the days without the fires (16 and 21 July 2019). The perturbations in the relative humidity along the vertical column with favorable atmospheric conditions could initiate cloud formation. Large aerosol backscatter coefficient values are observed below $2 \mathrm{~km}$ altitude (see Figure 6c). This is due to the high aerosol loading from the biomass burning. The highest aerosol backscatter coefficient value of $11 \mathrm{Mm}^{-1} \cdot \mathrm{sr}^{-1}$ is observed at an altitude of approximately $0.5 \mathrm{~km}$. Generally, the aerosol backscatter coefficient decreases with increasing altitude. However, a peak is observed at an altitude of approximately $4 \mathrm{~km}$. This peak corresponds to the smoke aerosols. This result is confirmed by the aerosol layer fraction profile in Figure 6d. Figure $6 \mathrm{~d}$ shows three distinct aerosol layers and the thickness for each layer can be estimated. The first layer is between ground and $1 \mathrm{~km}$, with an estimated thickness of approximately $1 \mathrm{~km}$. This is the layer (PBL) where most of the biomass burning aerosols, gases and smoke is found. The second and third layers are found in the $4-6 \mathrm{~km}$, and 7-8 km altitudes, respectively. The second layer has an estimated thickness of approximately $2 \mathrm{~km}$, while the third layer has an estimated $1 \mathrm{~km}$ thickness. In both these layers smoke is the dominant constituent.
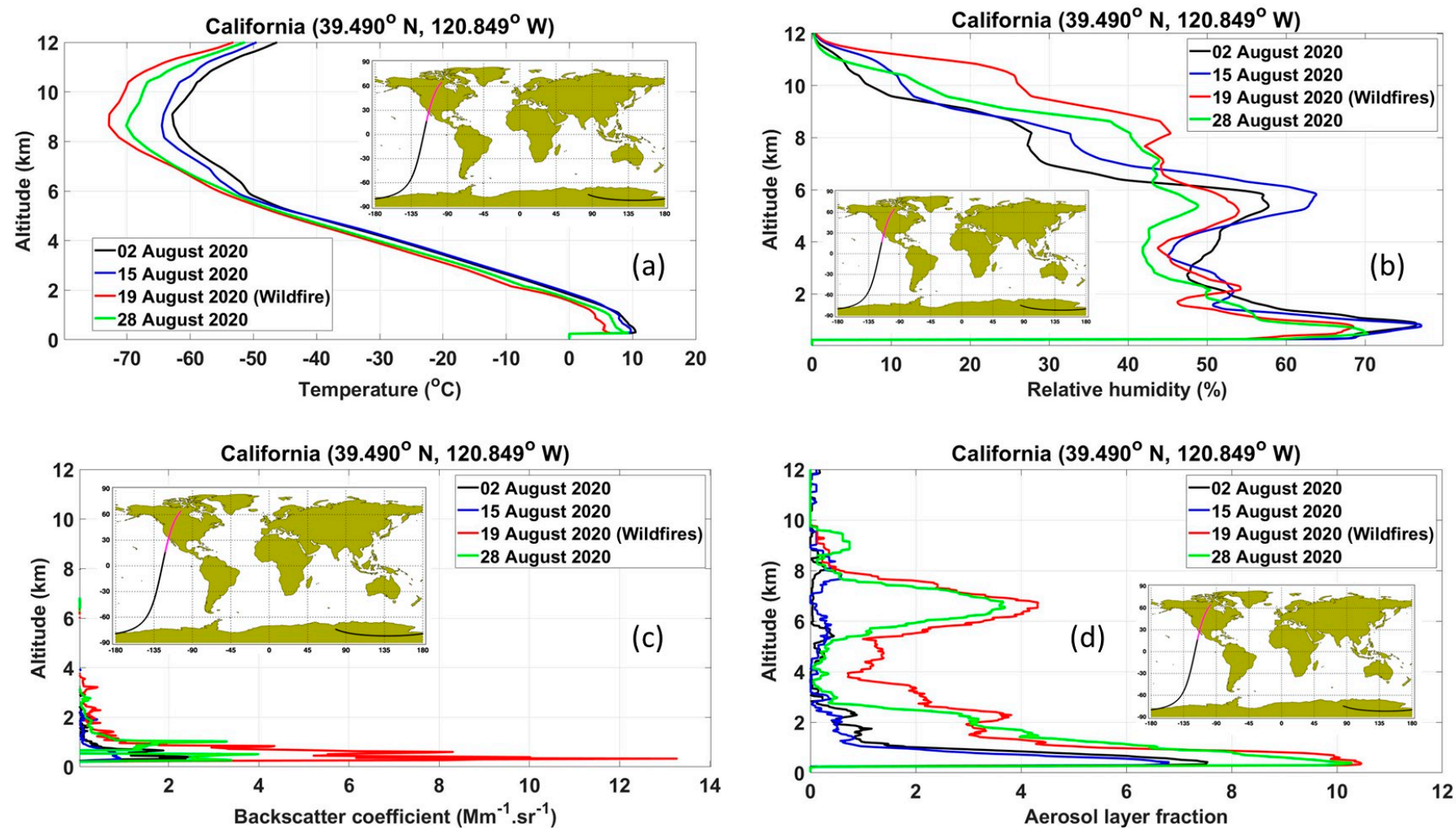

Figure 5. CALIOP vertical height profile over California for (a) temperature, (b) relative humidity, (c) backscatter coefficient and (d) aerosol layer fraction. 

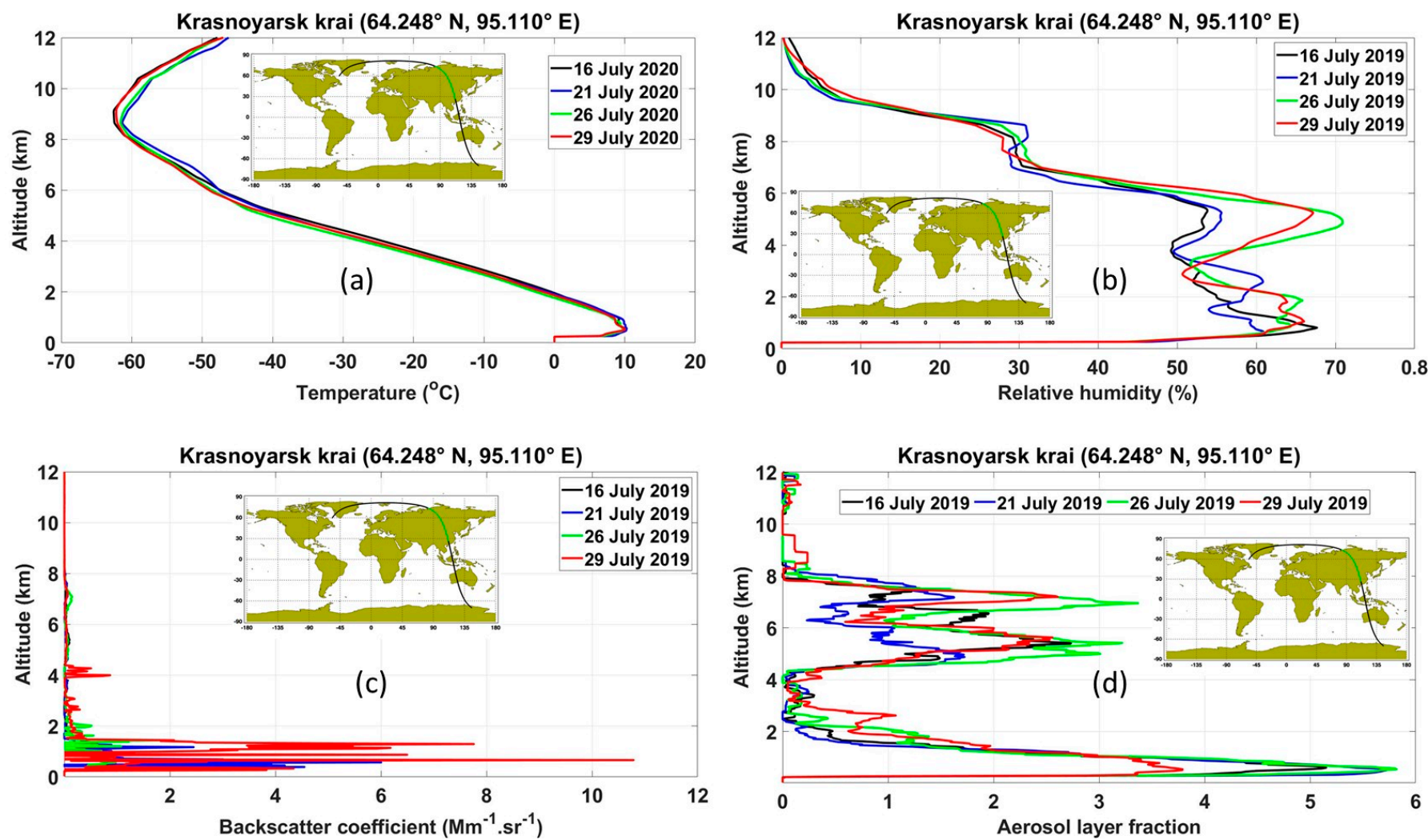

Figure 6. CALIOP vertical height profile over Krasnoyarsk Krai for (a) temperature, (b) relative humidity, (c) backscatter coefficient and (d) aerosol layer fraction.

\subsection{Transport of the Pollutants}

The movement of pollutants in the atmosphere is caused by transport, dispersion, and deposition. The transport is caused by the movement of massive amounts of air mass. Therefore, air mass trajectory shows the pathway of an infinitesimal air parcel through a centerline of an advected air mass having vertical and horizontal dispersion [52]. The forward trajectory estimates the pathway to be followed by an air parcel downwind from the selected coordinates in due course of time [53]. Figure 7a,b shows 5-day forward trajectories at different altitudes from a point California starting on 17 August 2020 and 19 August 2020 respectively. On 17 August 2020 (see Figure 7a) air mass traveling from $500 \mathrm{~m}$ travelled as high as $3500 \mathrm{~m}$ (on day 4) but on day 5 the air mass was observed at a height of approximately $1500 \mathrm{~m}$ which is likely to be the PBL. The airmass starting at a height of $2000 \mathrm{~m}$ also ended but at a height of approximately $1500 \mathrm{~m}$ on day 5 . This result implies that at these levels the pollutants are trapped in the PBL. The implication of this is that the pollutants may induce feedback to PBL structure and undergo physical/chemical transformations, which are relevant to meteorological factors such as humidity, temperature, and solar radiation [54]. Furthermore, the $500 \mathrm{~m}$ air mass travelled in an easterly and south easterly direction. The air mass travelled over the states of Nevada and Utah likely transporting the pollutants in these regions. The $2000 \mathrm{~m}$ air mass, on the other hand, travelled in a north eastly direction reaching the state of North Dakota. The $6000 \mathrm{~m}$ air mass ended up southeast from the source point in the state of New Mexico. On 19 August 2020 (see Figure $7 \mathrm{~b}$ ) air mass traveling from a height of $1000 \mathrm{~m}$ travelled as high as $3000 \mathrm{~m}$ until settling to a height of $1500 \mathrm{~m}$ after 5 days. The air mass travelled in a north easterly direction and ended up in South Dakota on day 5 of the trajectory. The air mass starting at $7000 \mathrm{~m}$ showed a very different behavior compared to the other trajectories discussed previously. The air mass started at a height of $7000 \mathrm{~m}$ and ended up at a height of $4500 \mathrm{~m}$ after 5 days. This is a height well above the PBL and it is in the free troposphere. Pollutants in the free troposphere have a longer lifetime as there is no deposition to the surface and temperatures 
are colder. Longer lifetimes of pollutants mean a greater chance for long-range transport to occur. The consequence transport means what was a local air pollution problem could turn into a regional or global problem [55].
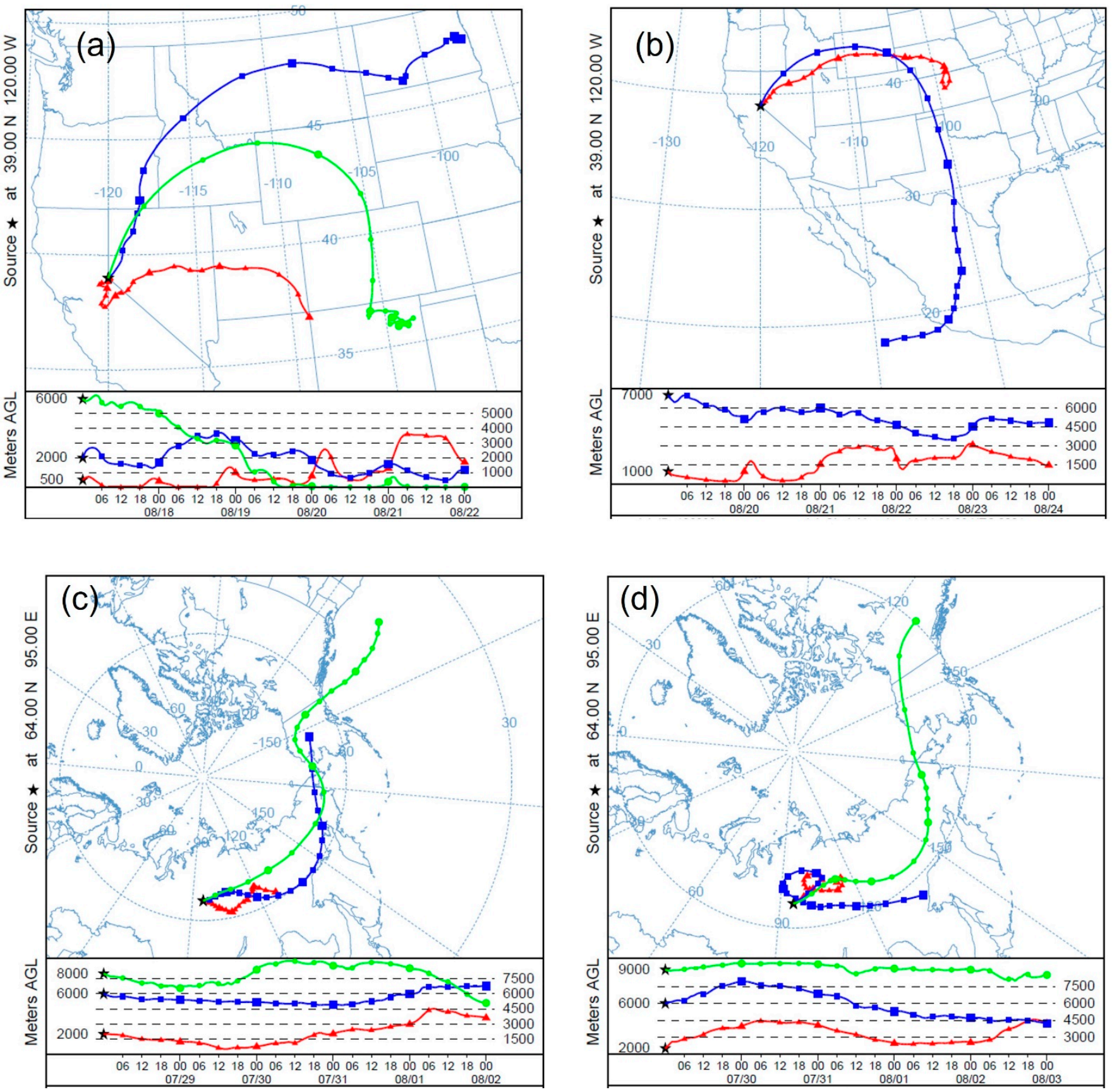

Figure 7. (a) Air mass forward trajectories starting on 17 August 2020 in California at 500 m, $2000 \mathrm{~m}$ and $6000 \mathrm{~m}$ above ground level. (b) Forward trajectories starting on 19 August 2020 at $1000 \mathrm{~m}$ and $7000 \mathrm{~m}$ above ground level. (c) Air mass forward trajectories starting on 28 July 2019 in Krasnoyarsk Krai at $2000 \mathrm{~m}, 6000 \mathrm{~m}$ and $8000 \mathrm{~m}$ above ground level. (d) Forward trajectories starting on 29 July 2019 at $2000 \mathrm{~m}, 6000 \mathrm{~m}$ and $9000 \mathrm{~m}$ above ground level.

Figure 7c,d shows 5-day forward trajectories at different altitudes from a point in Krasnoyarsk Krai starting on 28 July 2019 and 29 July 2019 respectively. On 28 July 2019 (see Figure 7c), at the starting height of $2000 \mathrm{~m}$, the air mass ended up at a height of $3500 \mathrm{~m}$ after 5 days. This result suggests that some aerosols and smoke could have been transported 
out of the PBL and ended up in the $3500 \mathrm{~m}$ altitude which is the free troposphere. Once in the free troposphere, the aerosols are subjected to long-range transport. In the $2000 \mathrm{~m}$ altitude, the air mass travelled predominantly in an eastly direction ending up in the Republic of Sakha, in Russia. This short-range transport could have an impact in the local air quality and meteorology in this region. The $6000 \mathrm{~m}$ air mass ended up at an altitude of $6500 \mathrm{~m}$ after 5 days. The air mass travelled in a north eastly direction and ended up in Alaska in the United States of America. The $8000 \mathrm{~m}$ air mass also travelled along a similar route but ended up in the north Pacific Ocean after 5 days. The air mass ended up at an altitude of $5000 \mathrm{~m}$ after 5 days. The air masses transporting aerosols at these heights could play a role in the formation of clouds. On 29 July 2019 (see Figure 7d), at the starting point of $2000 \mathrm{~m}$, the air mass ended up at a height of $4500 \mathrm{~m}$ after 5 days. The air mass did not travel far but remained within the Krasnoyarsk Krai region. The $6000 \mathrm{~m}$ air mass had a similar trajectory as that of the $2000 \mathrm{~m}$ but after 5 days the air mass ended up at Republic of Sakha, in Russia. The air mass also ended up at a height of $4500 \mathrm{~m}$ which could have impacts on the climate and cloud formation. The $9000 \mathrm{~m}$ air mass travelled in a north easterly direction and ended up in Canada. The air mass ended up at a height of $8000 \mathrm{~m}$. A very low aerosol loading, and smoke is anticipated at these heights, refer to Figure $7 \mathrm{~b}$.

\section{Conclusions}

The wildfires' emissions from different geographical areas are expected to be different due to unique factors driving each fire such as fuel type, topology, and meteorology. California and the Krasnoyarsk Krai wildfires which occurred during 16-17 August 2020 and 28 July 2019, respectively, showed some differences in the emissions. One of the defining factors for the differences in the emissions is the fact that fuel load and the burnt area (not shown in this study) are different in the two regions. This, of course, has a huge impact on the density, concentration, and transport on the emitted pollutants. As an example, the aerosol extinction coefficient profile showed smoke detected at the highest altitude of $9 \mathrm{~km}$ in Krasnoyarsk Krai whereas, in California the highest altitude was observed at approximately $6 \mathrm{~km}$. Moreover, large values of BC concentration were observed in Krasnoyarsk Krai approximately $7 \mu \mathrm{g} / \mathrm{m}^{3}$ compared to the $0.44 \mu \mathrm{g} / \mathrm{m}^{3}$ observed in California. This study showed that areas with an immense dense vegetation are prone to large emissions. The results from this case study suggests that high-latitude wildfires emit more pollutants than mid-latitude wildfires. However, more studies in the future will be conducted to conclude this observation and finding with certainty.

Author Contributions: Conceptualization, L.S. and J.B.H.; methodology, L.S.; software, L.S.; formal analysis, L.S. and J.B.H.; investigation, L.S. and J.B.H.; data curation, L.S.; writing-original draft preparation, L.S.; writing-review and editing, L.S. and J.B.H. All authors have read and agreed to the published version of the manuscript.

Funding: This research received no external funding, and the APC was funded by the South African National Space Agency.

Institutional Review Board Statement: Not applicable.

Informed Consent Statement: Not applicable.

Data Availability Statement: The data that support the findings of this study are openly available in https:/ / giovanni.gsfc.nasa.gov/giovanni/, https:/ / code.earthengine.google.com/, https:/ / www. ready.noaa.gov/HYSPLIT_traj.php and https: / / urs.earthdata.nasa.gov/, accessed on 10 January 2022.

Acknowledgments: The author acknowledges the GES-DISC Interactive Online Visualization and Analysis Infrastructure (Giovanni) for providing the MERRA-2 data. The author thanks the NASA Langley Research Centre Atmospheric Science Data Centre for the CALIPSO data. We further thank and acknowledge ESA for the Sentinel-5 P/TROPOMI data. Lastly, the authors gratefully acknowledge the NOAA Air Resources Laboratory (ARL) for the provision of the HYSPLIT transport and dispersion model and/or READY website (http:/ / www.ready.noaa.gov, accessed on 10 January 2022) used in this publication. 
Conflicts of Interest: The authors declare no conflict of interest.

\section{References}

1. Pyne, S.J.; Andrews, P.L.; Laven, R.D. Introduction to Wildland Fire; John Wiley \& Sons: New York, NY, USA, 1996; 769p.

2. Bodí, M.B.; Martin, D.A.; Balfour, V.N.; Santín, C.; Doerr, S.H.; Pereira, P.; Cerdà, A.; Mataix-Solera, J. Wildland fire ash: Production, composition and eco-hydro-geomorphic effects. Earth Sci. Rev. 2014, 130, 103-127. [CrossRef]

3. Miller, J.D.; Yool, S.R. Mapping forest post-fire canopy consumption in several overstory types using multi-temporal Landsat TM and ETM data. Remote Sens. Environ. 2002, 82, 481-496. [CrossRef]

4. Ruffault, J.; Curt, T.; Moron, V.; Trigo, R.M.; Mouillot, F.; Koutsias, N.; Pimont, F.; Martin-St Paul, N.; Barbero, R.; Dupuy, J.-L.; et al. Increased likelihood of heat-induced large wildfires in the Mediterranean Basin. Sci. Rep. 2020, 10, 13790. [CrossRef]

5. Littell, J.S.; McKenzie, D.; Peterson, D.L.; Westerling, A.L. Climate and wildfire area burned in western U.S. ecoprovinces, 1916-2003. Ecol. Appl. 2009, 19, 1003-1021. [CrossRef]

6. Barbero, R.; Abatzoglou, J.T.; Kolden, C.A.; Hegewisch, K.C.; Larkin, N.K.; Podschwit, H. Multi-scalar influence of weather and climate on very large-fires in the Eastern United States. Int. J. Clim. 2015, 35, 2180-2186. [CrossRef]

7. Jiang, Y.; Yang, X.-Q.; Liu, X.; Qian, Y.; Zhang, K.; Wang, M.; Li, F.; Wang, Y.; Lu, Z. Impacts of Wildfire Aerosols on Global Energy Budget and Climate: The Role of Climate Feedbacks. J. Clim. 2020, 33, 3351-3366. [CrossRef]

8. Kganyago, M.; Shikwambana, L. Assessment of the Characteristics of Recent Major Wildfires in the USA, Australia and Brazil in 2018-2019 Using Multi-Source Satellite Products. Remote Sens. 2020, 12, 1803. [CrossRef]

9. Bencherif, H.; Bègue, N.; Kirsch Pinheiro, D.; du Preez, D.J.; Cadet, J.M.; da Silva Lopes, F.J.; Shikwambana, L.; Landulfo, E.; Vescovini, T.; Labuschagne, C.; et al. Investigating the Long-Range Transport of Aerosol Plumes Following the Amazon Fires (August 2019): A Multi-Instrumental Approach from Ground-Based and Satellite Observations. Remote. Sens. 2020, $12,3846$. [CrossRef]

10. Marengo, J.A.; Cunha, A.P.; Cuartas, L.A.; Deusdará, L.K.R.; Broedel, E.; Seluchi, M.E.; Michelin, C.M.; De Praga, B.C.F.; Chuchón, Â.E.; Almeida, E.K.; et al. Extreme Drought in the Brazilian Pantanal in 2019-2020: Characterization, Causes, and Impacts. Front. Water 2021, 3, 13. [CrossRef]

11. Shikwambana, L.; Kganyago, M. Observations of Emissions and the Influence of Meteorological Conditions during Wildfires: A Case Study in the USA, Brazil, and Australia during the 2018/19 Period. Atmosphere 2021, 12, 11. [CrossRef]

12. Jost, H.J.; Drdla, K.; Stohl, A.; Pfister, L.; Loewenstein, M.; Lopez, J.P.; Hudson, P.K.; Murphy, D.M.; Cziczo, D.J.; Fromm, M.; et al. In-situ observations of mid-latitude forest fire plumes deep in the stratosphere. Geophys. Res. Lett. 2004, 31. [CrossRef]

13. Fromm, M.; Lindsey, D.T.; Servranckx, R.; Yue, G.; Trickl, T.; Sica, R.; Doucet, P.; Godin-Beekmann, S. The Untold Story of Pyrocumulonimbus. Bull. Am. Meteorol. Soc. 2010, 91, 1193-1210. [CrossRef]

14. Peterson, D.A.; Campbell, J.R.; Hyer, E.J.; Fromm, M.D.; Kablick, G.; Cossuth, J.H.; Deland, M.T. Wildfire-driven thunderstorms cause a volcano-like stratospheric injection of smoke. NPJ Clim. Atmos. Sci. 2018, 1, 30. [CrossRef] [PubMed]

15. Lentile, L.B.; Holden, Z.A.; Smith, A.M.S.; Falkowski, M.J.; Hudak, A.T.; Morgan, P.; Lewis, S.A.; Gessler, P.E.; Benson, N.C. Remote sensing techniques to assess active fire characteristics and post-fire effects. Int. J. Wildland Fire 2006, 15, 319-345. [CrossRef]

16. Andreae, M.O.; Merlet, P. Emission of trace gases and aerosols from biomass burning. Glob. Biogeochem. Cycles 2001, 15, 955-966. [CrossRef]

17. Smith, A.M.S.; Wooster, M.J.; Drake, N.A.; Dipotso, F.M.; Perry, G.L.W. Fire in African Savanna: Testing the Impact of Incomplete Combustion on Pyrogenic Emissions Estimates. Ecol. Appl. 2005, 15, 1074-1082. [CrossRef]

18. Guo, M.; Li, J.; Xu, J.; Wang, X.; He, H.; Wu, L. $\mathrm{CO}_{2}$ emissions from the 2010 Russian wildfires using GOSAT data. Environ. Pollut 2017, 226, 60-68. [CrossRef]

19. Kostrykin, S.; Revokatova, A.; Chernenkov, A.; Ginzburg, V.; Polumieva, P.; Zelenova, M. Black Carbon Emissions from the Siberian Fires 2019: Modelling of the Atmospheric Transport and Possible Impact on the Radiation Balance in the Arctic Region. Atmosphere 2021, 12, 814. [CrossRef]

20. Vadrevu, K.P.; Lasko, K.; Giglio, L.; Justice, C. Vegetation fires, absorbing aerosols and smoke plume characteristics in diverse biomass burning regions of Asia. Environ. Res. Lett. 2015, 10, 105003. [CrossRef]

21. Das, S.; Harshvardhan, H.; Bian, H.; Chin, M.; Curci, G.; Protonotariou, A.P.; Mielonen, T.; Zhang, K.; Wang, H.; Liu, X. Biomass burning aerosol transport and vertical distribution over the South African-Atlantic region. J. Geophys. Res. Atmos. 2017, 122, 6391-6415. [CrossRef]

22. Gonzalez-Alonso, L.; Val Martin, M.; Kahn, R.A. Biomass-burning smoke heights over the Amazon observed from space. Atmos. Chem. Phys. 2019, 19, 1685-1702. [CrossRef]

23. Rizza, U.; Mancinelli, E.; Morichetti, M.; Passerini, G.; Virgili, S. Aerosol Optical Depth of the Main Aerosol Species over Italian Cities Based on the NASA/MERRA-2 Model Reanalysis. Atmosphere 2019, 10, 709. [CrossRef]

24. Shikwambana, L.; Ncipha, X.; Malahlela, O.E.; Mbatha, N.; Sivakumar, V. Characterisation of aerosol constituents from wildfires using satellites and model data: A case study in Knysna, South Africa. Int. J. Remote Sens. 2019, 40, 4743-4761. [CrossRef]

25. Vadrevu, K.P.; Ellicott, E.; Badarinath, K.V.S.; Vermote, E. MODIS derived fire characteristics and aerosol optical depth variations during the agricultural residue burning season, north India. Environ. Pollut. 2011, 159, 1560-1569. [CrossRef] 
26. Ångström, A. On the Atmospheric Transmission of Sun Radiation and on Dust in the Air. Geogr. Ann. 1929, 11, 156-166. [CrossRef]

27. Liu, C.; Chung, C.E.; Yin, Y.; Schnaiter, M. The absorption Ångström exponent of black carbon: From numerical aspects. Atmos. Chem. Phys. 2018, 18, 6259-6273. [CrossRef]

28. Pathak, T.B.; Maskey, M.L.; Dahlberg, J.A.; Kearns, F.; Bali, K.M.; Zaccaria, D. Climate Change Trends and Impacts on California Agriculture: A Detailed Review. Agronomy 2018, 8, 25. [CrossRef]

29. Leskinen, P.; Lindner, M.; Verkerk, P.J.; Nabuurs, G.J.; Van Brusselen, J.; Kulikova, E.; Hassegawa, M.; Lerink, B. Russian forests and climate change. What Science Can Tell Us 11. Eur. For. Inst. 2020. [CrossRef]

30. Greenpeace. 2001. Available online: https://www.greenpeace.org/static/planet4-netherlands-stateless/2018/06/west-siberiaoil-industry-envi.pdf (accessed on 15 December 2021).

31. Kharlamova, N.; Sukhova, M.; Chlachula, J. Present climate development in Southern Siberia: A 55-year weather observations record. IOP Conf. Ser. Earth Environ. Sci. 2019, 395, 012027. [CrossRef]

32. Hunt, W.H.; Winker, D.M.; Vaughan, M.A.; Powell, K.A.; Lucker, P.L.; Weimer, C. CALIPSO Lidar Description and Performance Assessment. J. Atmos. Ocean. Technol. 2009, 26, 1214-1228. [CrossRef]

33. Winker, D.M.; Vaughan, M.A.; Omar, A.; Hu, Y.; Powell, K.A.; Liu, Z.; Hunt, W.H.; Young, S. Overview of the CALIPSO Mission and CALIOP Data Processing Algorithms. J. Atmos. Ocean. Technol. 2009, 26, 2310-2323. [CrossRef]

34. Winker, D.M.; Hunt, W.H.; McGill, M.J. Initial performance assessment of CALIOP. Geophys. Res. Lett. 2007, 34, L19803. [CrossRef]

35. Omar, A.H.; Winker, D.M.; Vaughan, M.A.; Hu, Y.; Trepte, C.R.; Ferrare, R.A.; Lee, K.-P.; Hostetler, C.A.; Kittaka, C.; Rogers, R.R.; et al. The CALIPSO Automated Aerosol Classification and Lidar Ratio Selection Algorithm. J. Atmos. Ocean. Technol. 2009, 26, 1994-2014. [CrossRef]

36. Vaughan, M.A.; Powell, K.A.; Kuehn, R.E.; Young, S.A.; Winker, D.M.; Hostetler, C.A.; Hunt, W.H.; Liu, Z.Y.; McGill, M.J.; Getzewich, B.J. Fully Automated Detection of Cloud and Aerosol Layers in the CALIPSO Lidar Measurements. J. Atmos. Ocean. Technol. 2009, 26, 2034-2050. [CrossRef]

37. Theys, N.; Hedelt, P.; De Smedt, I.; Lerot, C.; Yu, H.; Vlietinck, J.; Pedergnana, M.; Arellano, S.; Galle, B.; Fernandez, D.; et al. Global monitoring of volcanic $\mathrm{SO}_{2}$ degassing with unprecedented resolution from TROPOMI onboard Sentinel-5 Precursor. Sci. Rep. 2019, 9, 2643. [CrossRef]

38. Tilstra, L.G.; de Graaf, M.; Wang, P.; Stammes, P. In-orbit Earth reflectance validation of TROPOMI on board the Sentinel-5 Precursor satellite. Atmos. Meas. Tech. 2020, 13, 4479-4497. [CrossRef]

39. Verhoelst, T.; Compernolle, S.; Pinardi, G.; Lambert, J.-C.; Eskes, H.J.; Eichmann, K.-U.; Fjæraa, A.M.; Granville, J.; Niemeijer, S.; Cede, A.; et al. Ground-based validation of the Copernicus Sentinel-5P TROPOMI NO2 measurements with the NDACC ZSL-DOAS, MAX-DOAS and Pandonia global networks. Atmos. Meas. Tech. 2021, 14, 481-510. [CrossRef]

40. Justice, C.O.; Townshend, J.R.G.; Vermote, E.F.; Masuoka, E.; Wolfe, R.E.; Saleous, N.; Roy, D.P.; Morisette, J.T. An overview of MODIS Land data processing and product status. Remote Sens. Environ. 2002, 83, 3-15. [CrossRef]

41. Randles, C.A.; Da Silva, A.M.; Buchard, V.; Colarco, P.R.; Darmenov, A.; Govindaraju, R.; Smirnov, A.; Holben, B.; Ferrare, R.; Hair, J.; et al. The MERRA-2 Aerosol Reanalysis, 1980 Onward. Part I: System Description and Data Assimilation Evaluation. J. Clim. 2017, 30, 6823-6850. [CrossRef]

42. Wargan, K.; Labow, G.; Frith, S.; Pawson, S.; Livesey, N.; Partyka, G. Evaluation of the Ozone Fields in NASA's MERRA-2 Reanalysis. J. Clim. 2017, 30, 2961-2988. [CrossRef]

43. Gelaro, R.; McCarty, W.; Suárez, M.J.; Todling, R.; Molod, A.; Takacs, L.; Randles, C.A.; Darmenov, A.; Bosilovich, M.G.; Reichle, R.; et al. The Modern-Era Retrospective Analysis for Research and Applications, Version 2 (MERRA-2). J. Clim. 2017, 30, 5419-5454. [CrossRef] [PubMed]

44. Buchard, V.; Randles, C.A.; Da Silva, A.M.; Darmenov, A.; Colarco, P.R.; Govindaraju, R.; Ferrare, R.; Hair, J.; Beyersdorf, A.J.; Ziemba, L.D.; et al. The MERRA-2 Aerosol Reanalysis, 1980 Onward. Part II: Evaluation and Case Studies. J. Clim. 2017, 30, 6851-6872. [CrossRef] [PubMed]

45. Stein, A.F.; Draxler, R.R.; Rolph, G.D.; Stunder, B.J.B.; Cohen, M.D.; Ngan, F. NOAA's HYSPLIT Atmospheric Transport and Dispersion Modeling System. Bull. Am. Meteorol. Soc. 2015, 96, 2059-2077. [CrossRef]

46. Fleming, Z.L.; Monks, P.S.; Manning, A.J. Review: Untangling the influence of air-mass history in interpreting observed atmospheric composition. Atmos. Res. 2012, 104-105, 1-39. [CrossRef]

47. Draxler, R.R. Evaluation of an Ensemble Dispersion Calculation. J. Appl. Meteorol. 2003, 42, 308-317. [CrossRef]

48. Gaubert, B.; Worden, H.M.; Arellano, A.F.J.; Emmons, L.K.; Tilmes, S.; Barré, J.; Martinez-Alonso, S.; Vitt, F.; Anderson, J.L.; Alkemade, F.; et al. Chemical Feedback from Decreasing Carbon Monoxide Emissions. Geophys. Res. Lett. 2017, 44, 9985-9995. [CrossRef]

49. Petzold, A.; Ogren, J.A.; Fiebig, M.; Laj, P.; Li, S.-M.; Baltensperger, U.; Holzer-Popp, T.; Kinne, S.; Pappalardo, G.; Sugimoto, N.; et al. Recommendations for reporting "black carbon" measurements. Atmos. Chem. Phys. 2013, 13, 8365-8379. [CrossRef]

50. Duc, H.N.; Shingles, K.; White, S.; Salter, D.; Chang, L.T.-C.; Gunashanhar, G.; Riley, M.; Trieu, T.; Dutt, U.; Azzi, M.; et al. Spatial-Temporal Pattern of Black Carbon (BC) Emission from Biomass Burning and Anthropogenic Sources in New South Wales and the Greater Metropolitan Region of Sydney, Australia. Atmosphere 2020, 11, 570. [CrossRef] 
51. Russell, P.B.; Bergstrom, R.W.; Shinozuka, Y.; Clarke, A.D.; DeCarlo, P.F.; Jimenez, J.L.; Livingston, J.M.; Redemann, J.; Dubovik, O.; Strawa, A. Absorption Angstrom Exponent in AERONET and related data as an indicator of aerosol composition. Atmos. Chem. Phys. 2010, 10, 1155-1169. [CrossRef]

52. Kulshrestha, U.; Kumar, B. Airmass Trajectories and Long Range Transport of Pollutants: Review of Wet Deposition Scenario in South Asia. Adv. Meteorol. 2014, 2014, 596041. [CrossRef]

53. Hernández-Ceballos, M.Á.; De Felice, L. Air Mass Trajectories to Estimate the "Most Likely" Areas to Be Affected by the Release of Hazardous Materials in the Atmosphere-Feasibility Study. Atmosphere 2019, 10, 253. [CrossRef]

54. Miao, Y.; Li, J.; Miao, S.; Che, H.; Wang, Y.; Zhang, X.; Zhu, R.; Liu, S. Interaction Between Planetary Boundary Layer and PM2.5 Pollution in Megacities in China: A Review. Curr. Pollut. Rep. 2019, 5, 261-271. [CrossRef]

55. Donnell, E.A.; Fish, D.J.; Dicks, E.M.; Thorpe, A.J. Mechanisms for pollutant transport between the boundary layer and the free troposphere. J. Geophys. Res. 2001, 106, 7847-7856. [CrossRef] 